Mikio Suzuki • Takeshi K. Watanabe - Tsutomu Fujiwara

Yusuke Nakamura • Ei-ichi Takahashi · Akira Tanigami

\title{
Molecular cloning, expression, and mapping of a novel human cDNA, GRP17, highly homologous to human gadd45 and murine MyD118
}

Received: March 23, 1999 / Accepted: April 10, 1999

\begin{abstract}
From a human placenta cDNA library, we isolated a novel gene whose predicted product is highly homologous in amino acid sequence to human gadd45 and murine $M y D 118$ proteins (about $55 \%$ and $52 \%$ identity, respectively). The cDNA clone, designated GRP17 (gaddrelated protein, $17 \mathrm{kDa}$ ), contained a $477-\mathrm{bp}$ open reading frame encoding 159 amino acids. Northern blot analysis revealed strong expression of a $1.35-\mathrm{kb}$ transcript in heart, placenta, liver, skeletal muscle, prostate, testis, and ovary. A 1.7-kb additional transcript was detected in liver. We assigned the GRP17 gene to chromosome 9q22.1-q22.2 by fluorescence in situ hybridization (FISH).
\end{abstract}

Keywords gadd45 $\cdot M y D 118 \cdot$ Acidic protein $\cdot$ Growth suppressor $\cdot 9 q 22$

\section{Introduction}

Growth arrest and apoptosis are important mechanisms for regulating cell numbers within a given tissue. A remarkable overlap has been observed between the "gadd" set of growth-arrest and DNA damage-inducible genes (Fornace et al. 1989), and the $M y D$ set of myeloid-differentiation primary response genes (Lord et al. 1990). Among these genes, gadd34/MyD116, gadd45, MyD118, and gadd153

M. Suzuki $\cdot$ T. K. Watanabe · T. Fujiwara $\cdot$ E. Takahashi

A. Tanigami $(\bowtie)$

Otsuka GEN Research Institute, Otsuka Pharmaceutical Co. Ltd.

463-10 Kagasuno, Kawauchi-cho, Tokushima 771-0192, Japan

Tel. +81-88-665-2888; Fax +81-88-637-1035

e-mail: atanigam@otsuka.gr.jp

Y. Nakamura

Laboratory of Molecular Medicine, Institute of Medical Science, The University of Tokyo, Tokyo, Japan share multiple properties, such as roles in growth control, unusual charge characteristics of their encoded acidic proteins, and similarities in expression and regulation. This group may define a novel gene family encoding acidic proteins that suppress cell growth in a synergistic manner (Zhan et al. 1994). However, the mechanisms involved remain unknown.

Although gadd45 (Carrier et al. 1994) and MyD118 (Abdollahi et al. 1991) are very similar in DNA sequences, they are distinct genes. Expression of gadd45 is inducible by a wide variety of stresses, and is regulated by $p 53$ (Hollander et al. 1993). Smith et al. (1994) have reported that GADD45 binds to proliferating cell nuclear antigen (PCNA) and stimulates repair of DNA excision. Other studies have indicated that GADD45 interacts with p21, cyclin-dependent kinase inhibitor, and modulates the cell cycle by inhibiting DNA replication (Chen et al. 1995; Kearsey et al. 1995).

Here we report nucleotide and deduced amino-acid sequences of a human cDNA clone whose encoded peptide is highly homologous to human gadd45 and murine MyD118. We also describe its expression pattern in adult human tissues, and document its chromosomal location.

\section{Materials and methods}

Cloning and DNA sequencing

As a part of the Human Genome Project, we determined the nucleotide sequences of cDNA clones randomly selected from human fetal brain, adult aorta, and placenta cDNA libraries, and have been comparing them by means of the FASTA program of the UWGCG package (Pearson and Lipman 1988). In the process, we found a 1.1-kb cDNA derived from the placenta cDNA library, termed GEN$554 \mathrm{H} 06$, that revealed a significant degree of homology to the human gadd45 and murine $M y D 118$ genes. Its nucleotide sequence was determined with an A.L.F. DNA sequencer (Amersham Pharmacia, Uppsala, Sweden) by the dideoxynucleotide chain-termination method. 
Fig. 1. Nucleotide and deduced amino acid sequences of GRP17. The in-frame termination codons are indicated by asterisks, and a polyadenylation signal is double-underlined. The nucleotide sequence reported in this paper will appear in the DDBJ, GenBank, and EMBL databases with accession number D83023

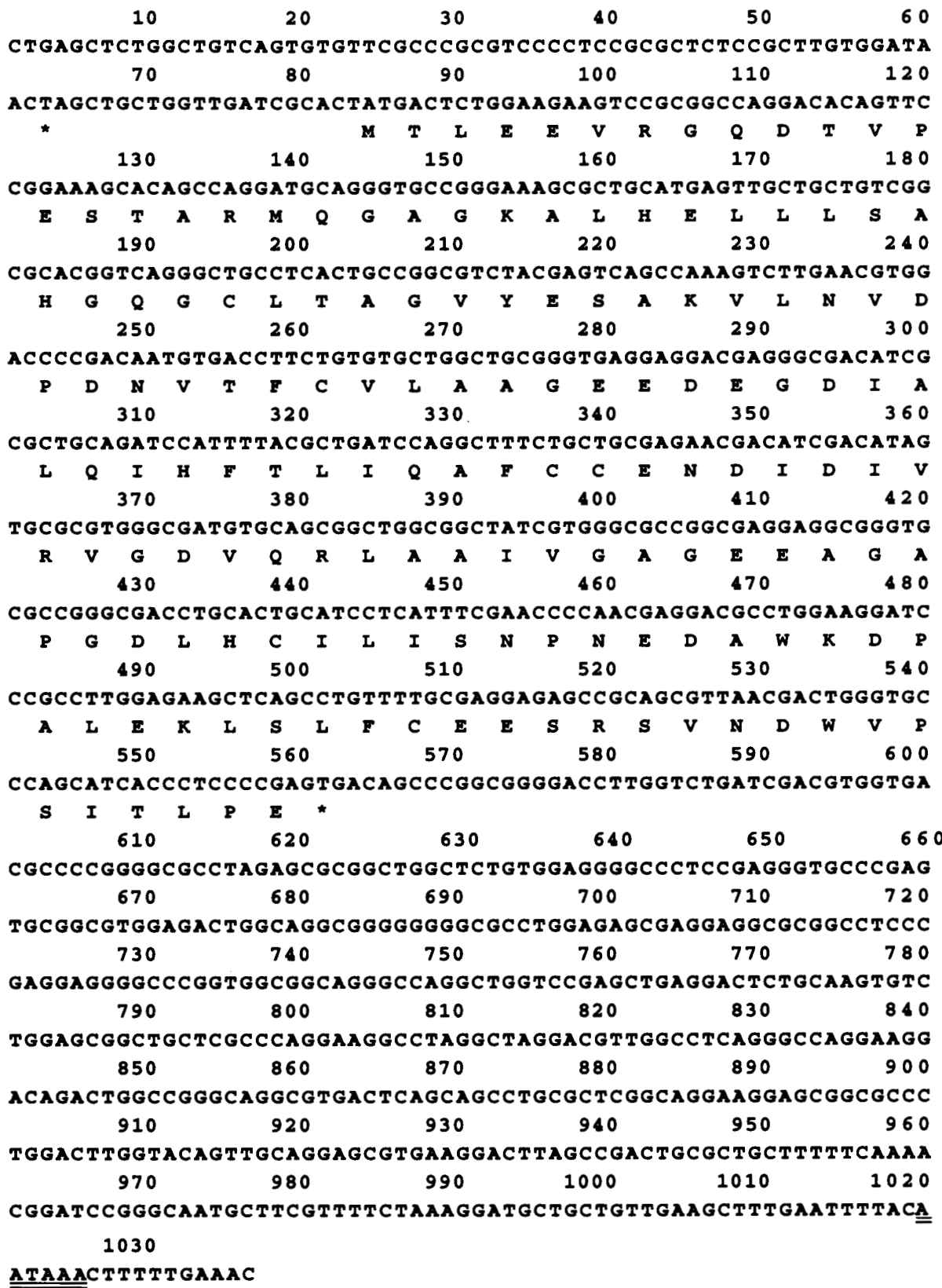

Northern blot analysis

Analysis of gene expression was carried out with a Human Multiple Tissue Northern (MTN) blot (Clontech, Palo Alto, CA, USA) according to the manufacturer's instructions. The entire cDNA sequence was purified, labeled with $\left[{ }^{32} \mathrm{P}\right]-$ dCTP (random-primed DNA labeling kit, Boehringer Mannheim, Tokyo, Japan), and used as a probe. The blot was prehybridized for $6 \mathrm{~h}$, then hybridized for $17 \mathrm{~h}$ at $42^{\circ} \mathrm{C}$ in a solution containing $50 \%$ formamide, $5 \times$ SSC, $10 \times$ Denhardt's solution, $2 \%$ SDS, and $0.1 \mu \mathrm{g} / \mathrm{ml}$ denatured salmon sperm DNA. The blot was washed with $2 \times$ SSC, $0.05 \%$ SDS for $10 \mathrm{~min}$ at room temperature, and then with $0.1 \times \mathrm{SSC}, 0.1 \% \mathrm{SDS}$ for $30 \mathrm{~min}$ at $65^{\circ} \mathrm{C}$. The membrane was autoradiographed at $-80^{\circ} \mathrm{C}$ for $7 \mathrm{~h}$.
Cosmid cloning and chromosomal localization by direct R-banding FISH

To isolate cosmid clones corresponding to the cDNA represented by GEN-554H06, we screened a total of 153600 cosmid clones by PCR amplification, using primers $\cos 1$ (5'-TAGGCTAGGACGTTGCCTCA-3') and cos 2 (5'GCTTCAACAGCAGCATCCTT-3'), with initial denaturation at $94^{\circ} \mathrm{C}$ for $1 \mathrm{~min}$, followed by 35 cycles of $94^{\circ} \mathrm{C}$ for 30 $\mathrm{s}, 55^{\circ} \mathrm{C}$ for $45 \mathrm{~s}$, and $72^{\circ} \mathrm{C}$ for $45 \mathrm{~s}$.

The three independent cosmid clones obtained were used as probes for mapping by direct R-banding fluorescence in situ hybridization (FISH), a method based on FISH combined with replicated pro-metaphase R-bands (Takahashi et al. 1990; 1991). For suppression of the repeti- 
Fig. 2. The predicted amino acid sequence of GRP17 is aligned with the sequences of human GADD45 and murine MyD118. Identical residues are shaded

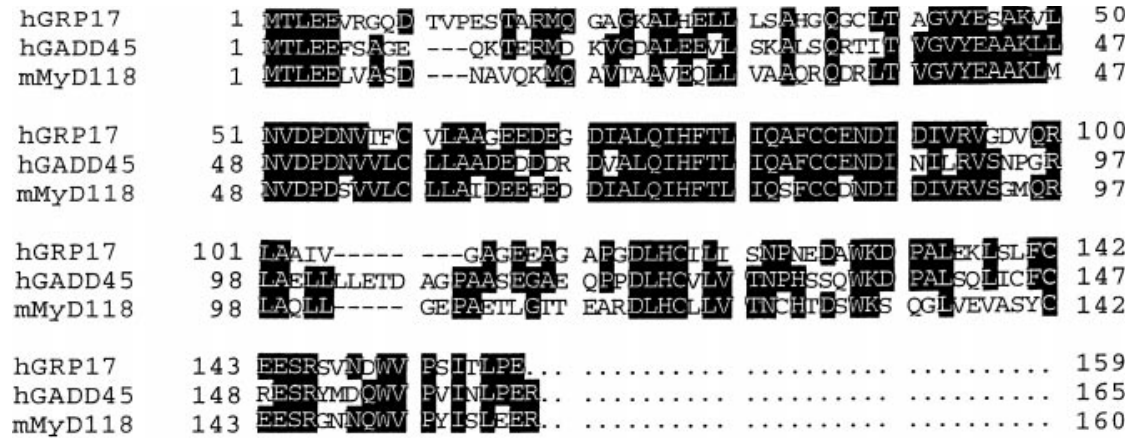

tive sequences contained in the cosmids we used human Cot1 DNA (Gibco BRL, Rockville, MD, USA) as described by Lichter et al. (1990), except that we used Cot-1 DNA in about 10-fold excess. Labeling, hybridization, rinsing, and detection were performed in a routine manner. Provia 100 film (ISO 100; Fujifilm, Tokyo, Japan) was used for the microphotography (filter combination, Nikon B-2A; Nikon, Tokyo, Japan).

\section{Results}

\section{Cloning and DNA sequencing of GRP17}

By examining databases we found that a cDNA clone, GEN-554H06, revealed significant homology with the human gadd45 and murine MyD118 genes. To confirm its putative open reading frame, we determined the entire coding sequence and the $5^{\prime}$ and $3^{\prime}$ flanking sequences, a total of 1036 nucleotides (Fig. 1). The predicted start codon was at nucleotides 84-86, the first ATG in the cDNA clone. Its sequence context (ACTATGA; nucleotides 81-87) was different from the optimal context, (A/G)CCATGG, for initiation of translation (Kozak 1987). However, its high sequence homology with human gadd45 at the nucleotide level strongly suggested that the ATG at nucleotides 84-86 was indeed the start codon. An optimal polyadenylation signal was followed by 17 nucleotides before the poly(A) start. The open reading frame consisted of 477 nucleotides, encoding a 159-amino-acid peptide with a calculated molecular weight of 17030 daltons and a calculated isoelectric point ( $\mathrm{pI}$ value) of about 4.06 , with a high percentage of negatively charged amino acids.

Similarity of the novel gene product to human gadd45 and murine $M y D 118$ proteins

Alignment of the new sequence with those of human gadd45 and murine $M y D 118$ revealed striking homologies at the amino-acid level (about $55 \%$ and $52 \%$ identity, respectively; Fig. 2). We therefore designated this molecule GRP17 (for gadd-related protein, 17kDa). Although no known motifs were identified, a region near the N-terminus of the predicted GRP17 peptide (aa 40-95) was conserved very well among the three proteins.

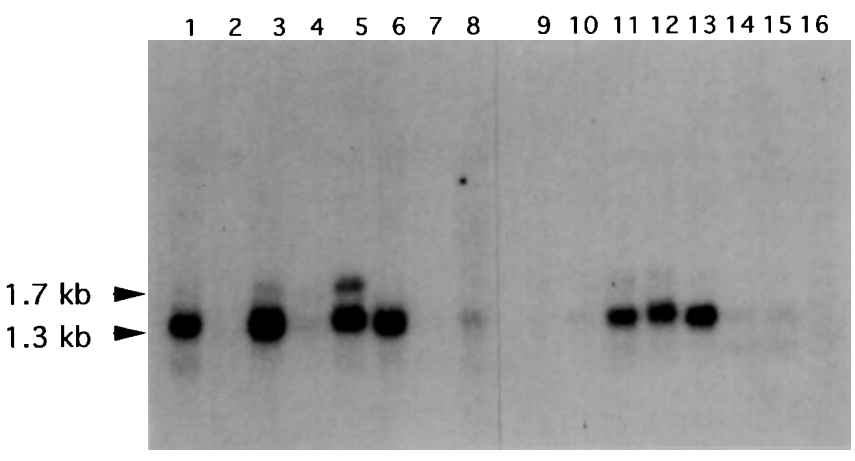

Fig. 3. Expression of GRP17 in human tissues. Each lane contains approximately $2 \mu \mathrm{g}$ of poly(A) RNA. Lanes $1-16$ contain, in order from left, RNAs from human heart, brain, placenta, lung, liver, skeletal muscle, kidney, pancreas, spleen, thymus, prostate, testis, ovary, small intestine, colon, and peripheral blood leukocytes

Expression of GRP17 in human tissues

Expression of the GRP17 mRNA in 16 normal adult human tissues was assessed by northern blotting using GEN554H06 as a probe (Fig. 3). We detected a major transcript of $1.35 \mathrm{~kb}$ in heart, placenta, liver, skeletal muscle, prostate, testis, and ovary. A $1.7-\mathrm{kb}$ additional transcript was detected in liver. By careful observation after overexposure $(17 \mathrm{~h})$, the $1.35-\mathrm{kb}$ transcript was detectable in brain, lung, pancreas, small intestine, and colon.

\section{Chromosomal localization of GRP17}

We isolated three independent cosmid clones corresponding to the GRP17 cDNA, and used these clones as probes for FISH. We performed direct R-banding FISH and observed 100 typical R-banded chromosome plates for each clone. The signals of all three clones were apparent only at band q22.1-q22.2 of chromosome 9 (Fig. 4).

\section{Discussion}

Gadd45 and MyD118, both of which encode acidic proteins, share unusual charge characteristics and their patterns of 


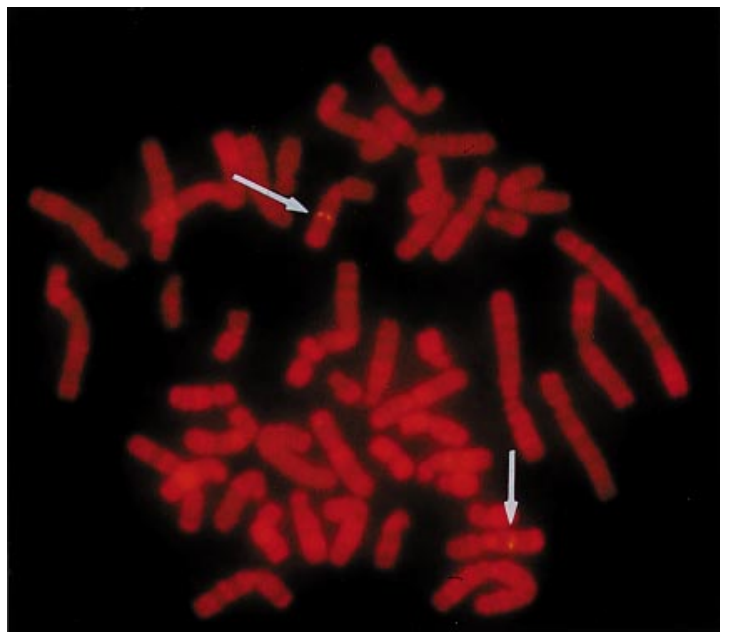

Fig. 4. Localization of GRP17 on R-banded metaphase chromosomes by fluorescence in situ hybridization (FISH). Arrows indicate the fluorescent signals on 9q22.1-q22.2

induction by a wide variety of stresses are similar. Moreover, both proteins function in a synergistic fashion as growth inhibitors, although the detailed mechanism involved is not yet known (Zhan et al. 1994). The sequence of GRP17 reported here shows significant similarity with gadd45 and $M y D 118$, and it also encodes an acidic protein. These data suggest that GRP17 is a novel member of a family of genes that encode acidic proteins involved in control of cellular growth. By isolating a human homologue of MyD118, we confirmed that GRP17 is not the human counterpart of this murine protein (data not shown). Although we have not examined the induction pattern or the function of GRP17, the significant sequence homologies imply that those features may be shared with the two related proteins.

Northern blot analysis revealed tissue-specific expression of GRP17 in normal adult tissues; the additional 1.7-kb transcript in liver could be produced by alternative splicing or derived from some other gene. Of great interest is the abundant expression of GRP17 in muscular tissues, testis, and ovary; that observation may imply an important role for GRP17 in differentiation of those organs.

We localized GRP17 to R-positive chromosomal band 9q22.1-q22.2. Around the region of 9q22, loss of heterozygosity has been reported to be found in bladder cancer (Simoneau et al. 1996). Hereditary sensory neuropathy 1 (HSN1) also has been mapped by linkage analysis in this region (9q22.1-q22.3, Nicholson GA et al. 1996). Detailed analysis at the molecular level will be needed for further understanding of the nature of GRP17 as well as the relation of the above diseases.
Acknowledgments We thank all the staff members of the GEN Research Institute. We also acknowledge Dr. Mitsuo Oshimura of Faculty of Medicine, Tottori University for helpful discussions.

\section{References}

Abdollahi A, Lord KA, Liebermann BH, Liebermann DA (1991) Sequence and expression of a cDNA encoding MyD118: a novel myeloid differentiation primary response gene induced by multiple cytokines. Oncogene 6:165-167

Carrier F, Smith ML, Bae I, Kilpatrick KE, Lansing TJ, Chen CY, Engelstein M, Friend SH, Henner WD, Gilmer TM, Kastan MB, Fornace AJ (1994) Characterization of human Gadd45, a p53 regulated protein. J Biol Chem 269:32672-32677

Chen IT, Smith ML, O'Connor PM, Fornace AJ (1995) Direct interaction of Gadd45 with PCNA and evidence for competitive interaction of Gadd45 and p21Waf1/Cip1 with PCNA. Oncogene 11:1931-1937

Fornace AJ, Nebert DW, Hollander MC, Luethy JD, Papathanasiou M, Fargnoli J, Holbrook NJ (1989) Mammalian genes coordinately regulated by growth arrest signals and DNA-damaging agents. Mol Cell Biol 9:4196-4203

Hollander MC, Alamo I, Jackman J, Wang MG, McBride OW, Fornace AJ (1993) Analysis of the mammalian gadd45 gene and its response to DNA damage. J Biol Chem 268:24385-24393

Kearsey JM, Coates PJ, Prescott AR, Warbrick E, Hall PA (1995) Gadd45 is a nuclear cell cycle regulated protein which interacts with p21Cip1. Oncogene 11:1675-1683

Kozak, M (1987) An analysis of 5'-noncoding sequences from 699 vertebrate messenger RNAs. Nucleic Acids Res 15:8125-8148

Lichter P, Ledbetter SA, Ledbetter DH, Ward DC (1990) Fluorescence in situ hybridization with Alu and L1 polymerase chain reaction probes for rapid characterization of human chromosomes in hybrid cell lines. Proc Natl Acad Sci USA 87:6634-6638

Lord KA, Liebermann BH, Liebermann DA (1990) Complexity of the immediate early response of myeloid cells to terminal differentiation and growth arrest includes ICAM-1, Jun-B and histone variants. Oncogene 5:387-396

Nicholson GA, Dawkins JL, Blair IP, Kennerson ML, Gordon MJ, Cherryson AK, Nash J, Bananis T (1996) The gene for hereditary sensory neuropathy type I (HSN-I) maps to chromosome 9q22.1q22.3. Nat Genet 13:101-104

Pearson WR, Lipman DJ (1988) Improved tools for biological sequence comparison. Proc Natl Acad Sci USA 85:2444-2448

Simoneau AR, Spruck CH, Gonzalez-Zulueta M, Gonzalgo ML, Chan MF, Tsai YC, Dean M, Steven K, Horn T, Jones PA (1996) Evidence for two tumor suppressor loci associated with proximal chromosome $9 \mathrm{p}$ to $\mathrm{q}$ and distal chromosome $9 \mathrm{q}$ in bladder cancer and the initial screening for GAS1 and PTC mutations. Cancer Res 56:5039-5043

Smith ML, Chen IT, Zhan Q, Bae I, Chen CY, Gilmer TM, Kastan MB, O'Conner PM, Fornace AJ (1994) Interaction of the p53-regulated protein gadd45 with proliferating cell nuclear antigen. Science 266:1376-1380

Takahashi E, Hori T, O'Connell P, Leppert M, White R (1990) Rbanding and nonisotopic in situ hybridization: precise localization of the human type II collagen gene (COL2A1). Hum Genet 86:14-16

Takahashi E, Yamauchi M, Tsuji H, Hitomi A, Meuth M, Hori T (1991) Chromosome mapping of the human cytidine-5'-triphosphate synthetase (CTPS) gene to band 1p34.1-p34.3 by fluorescence in situ hybridization. Hum Genet 88:119-121

Zhan Q, Lord KA, Alamo I, Hollander MC, Carrier F, Ron D, Hoffman B, Liebermann DA, Fornace, AJ (1994) The gadd45 and MyD genes define a novel set of mammalian genes encoding acidic proteins that synergistically suppress cell growth. Mol Cell Bio 14:2361-2371 